\title{
C 型肝炎
}

\section{思いもよらなかった薬物標的}

\section{An unsuspected drug target}

Catherine L. Murray and Charles M. Rice 2010 年 5 月 6 日号 Vol. 465 (42-44)

\section{C 型肝炎ウイルスの感染は肝疾患の主な原因の 1 つだが、幅広く有効な治療法が存在しない。 \\ 今回、このウイルスに対する全く新しい強力な阻害剤が発見された。 \\ このことは、既成概念にとらわれずに研究を行う大切さを示している。}

C 型肝炎ウイルス (HCV) はやっかい だ。慢性的な感染は、肝線維症や肝硬変、 肝細胞がんなどの肝疾患につながり、肝 移植が必要となる主要因となっている。 残念ながら、HCV ワクチンは存在せず、 既存の治療法は限定的で、患者への負担 が大きく、効果も不十分なことが多い。 そのため HCV 感染の予防と治療に対し て、明らかに新しい戦略が切望されてい る。このほど、Gao ら ${ }^{1}$ が、HCVの複 製を阻害する新しい物質を同定した。こ の物質は、「史上最強」の HCV 阻害剤 であるが、意外なことに、今まで考え られてきた HCVの「弱点」を突くもの ではない。この成果は Nature 2010 年 5 月 6 日号に発表された。今回の初期臨床 デー夕は今後に期待を抱かせるもので、 この阻害剂が次世代の抗 HCV 治療で中 心的な存在になる可能性を示している。

HCV が発見された 1989 年、ウイル スのタンパク質を特異的に狙う薬物が すぐに臨床化されるだろうと期待されて いた。しかし 20 年以上経った今も、患 者と医者は待たされ続けている。現在、 $\mathrm{HCV}$ 感染の標準的な治療法は、リバビ リンを 1 日 2 回服用しながらペグ化イン ターフェロン $\alpha$ を毎週注射することだ。 この 2 つの薬剤はいずれもウイルス感染 に対する汎用的な阻害剂で、うつ病やイ ンフルエンザ様症状などの重篤な副作用 を伴うことが多い。そればかりか、1 年 間治療を続けても回復するとはかぎら
ず、その治療効果は、患者の遺伝的変異 などの特性に加えて、ウイルスの系統 (遺 伝子型）などの特徵にも左右される ${ }^{2-4}$ 。 そのため別の治療手段が必要であり、長 年集中的な研究が推進されてきたが、こ こにきてようやく結実しつつある。

従来、薬剂開発で主要な標的となって きたのはウイルスの酵素だ。HCV の複製 には、2つのプロテアーゼ（NS2-3 およ びNS3-4A)、ヘリカーゼ (NS3)、そし てポリメラーゼ (NS5B) など、複数の HCV 酵素が必要である (図 1)。そのう ち、薬剤標的として、NS3-4A と NS5B は最も注目を集め、臨床試験では複数 の候補物質に有望な結果が出ている ${ }^{5,6}$ 。 しかし、HCV の複製は速度が速くエラー を起こしやすいため、薬剤耐性ウイル スが出現し、大きな問題となっている。 in vitro と in vivo の試験で、1つまたは 複数の物質に対する感受性を低下させる 変異が出現しているのだ ${ }^{5,6}$ 。而性ウイ ルスに対抗するには、おそらく抗ウイル 又薬の併用（理想的には作用機序が異な るものどうしの併用）が必要であり、研 究者たちはウイルス酵素以外の標的に目 を向けるようになった。

Gao らもそうした研究グループの 1 つだ。彼らは、HCV の複製を阻害する 物質を 100 万種以上の化合物からスク リーニングし、強力な抗ウイルス物質を 発見した ${ }^{1}$ 。新しい標的に的をしぼった 彼らの研究戦略は、次のようなものだつ
た。まず、生化学的検定法で、NS34A、NS5B、および HCV ヘリカーゼに 対する阻害活性が認められない物質だけ を選び出して、そのうえで、培養細胞中 でHCV の複製を抑制する候補物質を選 抜したのだ。こうして最初に同定された 物質は、幸運なことに、活性は弱いもの の、HCV の RNA 複製を特異的に阻害 するものだった ${ }^{7}$ 。幸運はもう1つ続い

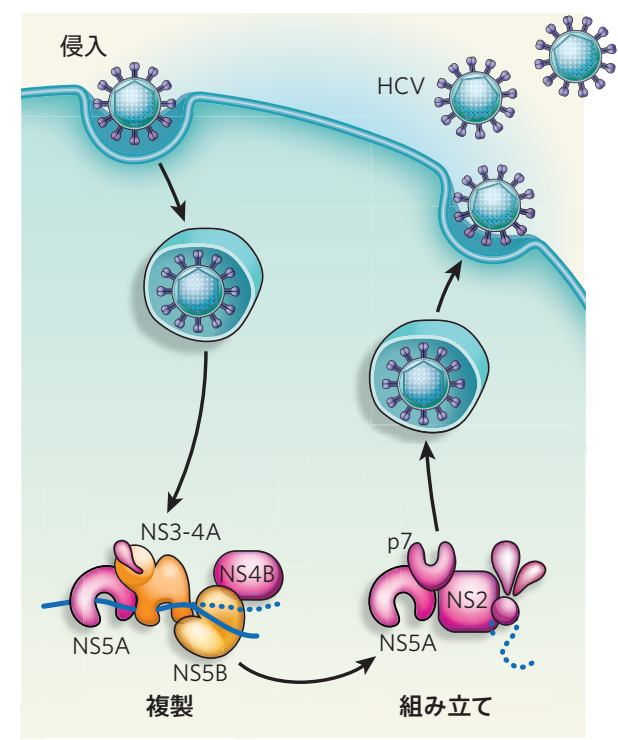

図 1.C 型肝炎ウイルス (HCV) の生活環。 HCV は宿主細胞に侵入すると、一連の酵素 を利用して複製を行う。従来は、NS3-4A や NS5B などの酵素が医薬品開発の標的であっ た (オレンジ色)。Gao ${ }^{1}$ は、NS5Aのよ うに酵素活性が知られていない HCV タンパ ク質 (ピンク色)に対する阻害剤開発について、 実現の可能性を示した。 
た。元のリード化合物（BMS-858）を 二量体化すると、阻害効果が格段に上昇 したのだ。これを最適化して生み出さ れたのがBMS-790052である（図 2)。 BMS-790052 は、試験対象にしたすべ ての HCV 遺伝子型で、ごく低い濃度で も特異的に複製を阻害する薬剤であり、 これまで知られている阻害剂の中で最も 強力であることがわかった。では、この 物質が作用する標的は何だろうか。

その手がかりは、BMS-790052 存在 下での HCV の長期培養により得られた。 耐性をもたらす変異が、NS5A という HCV タンパク質に現れたのだ。NS5A が怪しいというのは、共沈試験で BMS790052 と NS5A との相互作用を確認し たことで裏付けられた。

研究者にとって、NS5A は不思議な存 在だ。ウイルス RNA 増幅系の重要な因 子であり、また感染性をもつウイルス粒 子の組み立てでも中心的な役割を果たし ていることが知られている。そして両プ ロセスは共に、NS5A のリン酸化によっ て調節されている ${ }^{8,9}$ 。しかし、NS5A の酵素活性は不明で、HCV 生活環での 作用メカニズムもわかっていない。結 晶構造から、NS5A は二量体を形成する ことが明らかにされており ${ }^{10,11 、 そ の 二 ~}$ 量体が集合して大きなオリゴマーの配 列を形成し、RNA 基質を細胞内に取り 込んでいると考えられる。Gao ら ${ }^{1}$ は、 BMS-790052 の二量体構造が NS5A オ リゴマー形成を阻害し、連鎖的にコン フォメーション異常を引き起こす反応が 生じるために、強力な複製阻害作用を示 すのではないかと推測している。

この NS5A 阻害剂の初期臨床試験 ${ }^{1}$ はプラセボ対照試験から始められ、慢 性 HCV 感染患者に、さまざまな濃度の BMS-790052 が経口で単回投与された。 この薬剤の安全性と忍容性は十分と考え られ、24 時間にわたって高い血中濃度 が維持された。その結果、100mg 投与 した場合、1 日後の平均血中 HCV RNA 濃度はほぼ 2000 分の 1 に低下し、それ が丸 1 週間持続した。このことは、Gao

a

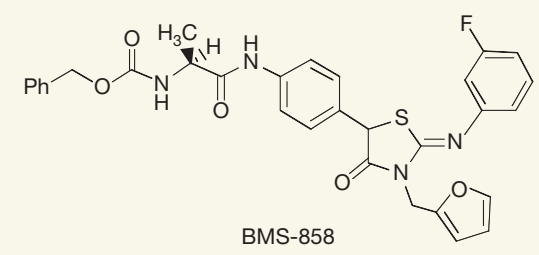

b

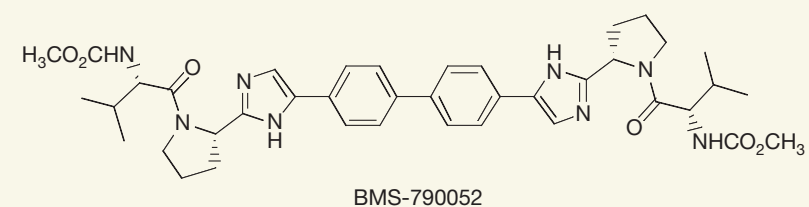

図 2.今回同定された候補物質の化学構造。a. 最初に同定された BMS-858には、阻 害活性が弱いものの特異性があった。b. a をもとに最適化された BMS-790052 には、 特異的かつ強力な阻害活性があった。

らを大いに勇気付けた。反復投与も含め、 今後の追跡臨床データが待ち望まれる。

今回、NS5Aを標的に有望な成果が 得られたことで、HCV の非酵素分子を 狙った物質を探索するという考え方が実 証された。長期試験や多剤併用試験でど のような結果が出るかは、まだわからな い。なぜなら、残念ながら多くの抗ウイ ルス剤候補が、有害な副作用のためにこ の段階で脱落するからである。しかし、 BMS-790052の強烈な有効性によって NS5A は極めて魅力的な標的へと変わ り、次世代の NS5A 阻害剤がまもなく 出現してくることは間違いない。

BMS-790052 が NS5A に直接作用し ていることを確認するにはさらに多くの 証拠が必要だ、と批評する人がいるかも しれない。共沈では間接的な相互作用も 検出されるし、耐性をもたらす変異は、 NS5A に関連する細胞因子やウイルス因 子に対する薬物作用を反映しているかも しれないからだ。標的を特定し、阻害 のメカニズムを明らかにするためには、 BMS-790052 と精製 NS5A との結合に 関する研究、最終的にはその複合体の結 晶構造の解析が極めて重要だろう。

BMS-790052 耐性ウイルスの特性を 解明するためのさらなる研究も必要だ。 それぞれの変異ウイルスがどのように 複製を可能にしているのかを明らかに
し、また、弱い薬剤而性をもつウイルス が、薬剤の長期投与によって別の変異を 獲得し、増殖するようになるのかどうか も見極める必要がある。それでも、今回 の画期的な研究により、薬剤標的として 従来の酵素以外の分子を狙うことが、よ うやく医薬品開発企業の利益に結びつ く可能性が示された。NS4B や p7 など (図 1) 機能が明らかにされていないほ かの HCV タンパク質に対する阻害剂や、 ウイルスと宿主タンパク質との重要な相 互作用の遮断剤が、同じようなスクリー ニング法で発見されるかもしれない。新 しい角度からウイルスに挑み続けること で、幅広い効果をもつ選択的な抗 $\mathrm{HCV}$ 剂療法という長年の目標をついに視野に とらえたのかもしれない。

(翻訳：小林盛方)

Catherine L. Murray および Charles M. Rice、 ロックフェラー大学ウイルス学感染症研究所 C 型肝炎研究セン夕ー (米国)。

1. Gao, M. et al. Nature $465,96-100$ (2010).

2. Ge, D. et al. Nature 461, 399-401 (2009).

3. Suppiah, V. et al. Nature Genet. 41,1100-1104 (2009)

4. Tanaka, Y.et al. Nature Genet. 41, 1105-1109 (2009).

5. De Francesco, R. \& Migliaccio, G. Nature 436, 953-960 (2005).

6. Kwong, A. D., McNair, L., Jacobson, I. \& George, S. Curr. Opin. Pharmacol. 8, 522-531 (2008).

7. Lemm, J. A. et al. J. Virol. 84, 482-491 (2010).

8. Tellinghuisen, T. L., Foss, K. L. \& Treadaway, J. PLoS Pathog. 4, e1000032 (2008).

9. Appel, N. et al. PLoS Pathog. 4, e1000035 (2008)

10. Tellinghuisen, T. L., Marcotrigiano, J. \& Rice, C. M. Nature 435, 374-379 (2005)

11. Love, R. A., Brodsky, O., Hickey, M. J., Wells, P. A. \& Cronin, C. N. J. Virol. 83, 4395-4403 (2009). 